\title{
The role of soils and land use in the greenhouse effect
}

\author{
A. F. BOUWMAN \\ International Soil Reference and Information Centre, P.O. Box 353, NL 6700 AJ Wagenin- \\ gen, Netherlands
}

Received 4 August 1988; accepted 7 November 1988

\begin{abstract}
The major greenhouse gases emitted by soils are $\mathrm{CO}_{2}, \mathrm{CH}_{4}, \mathrm{~N}_{2} \mathrm{O}$, $\mathrm{NO}$ and $\mathrm{CO}$. The annual rise of the atmospheric $\mathrm{CO}_{2}$ concentration is $0.5 \%$. Different modelling approaches of the biosphere are compared. The biosphere is at present a small sink of $\mathrm{CO}_{2}$ due to stimulation of growth by $\mathrm{CO}_{2}$. Continued global forest clearing will reduce this absorbing capacity. The $\mathrm{CH}_{4}$ concentration is rising with $1.1 \%$ per year, caused mainly by increasing areas of rice paddies, production of human wastes, numbers of ruminants, biomass burning and increasing nonbiogenic sources. Atmospheric $\mathrm{CO}$ is rising at a rate of 2 to $6 \%$ per year. Its major biogenic sources are biomass burning and vegetation. Soils act as a sink of CO. Its increase however, is caused mainly by oxidation of atmospheric methane and other hydrocarbons. The major biogenic sources of $\mathrm{N}_{2} \mathrm{O}$ and $\mathrm{NO}$ are soils (natural and cultivated), oceans and biomass burning. The increase of atmospheric $\mathrm{N}_{2} \mathrm{O}$ and $\mathrm{NO}$ is probably due to the increasing area of cultivated land and the global upward trend in the use of chemical fertilizers.
\end{abstract}

Keywords: greenhouse gases, carbon dioxide, methane, carbon monoxide, nitrous oxide, nitric oxide

\section{Introduction}

The earth's atmosphere absorbs thermal (infrared) energy which is emitted by the surface. This trapping of energy by radiative absorbers within the atmosphere elevates surface temperatures by several tens of degrees Centigrade above what they would be in the absence of an atmosphere (Dickinson, 1986a). The trapping of energy is commonly called the 'greenhouse effect'.

Atmospheric gases with absorption bands in the infrared region of the electromagnetic spectrum are called 'greenhouse gases'. The most important greenhouse gases emitted from soils and/or their land cover are carbon dioxide $\left(\mathrm{CO}_{2}\right)$, methane $\left(\mathrm{CH}_{4}\right)$, carbon monoxide (CO), nitrous oxide $\left(\mathrm{N}_{2} \mathrm{O}\right)$, nitric oxide (NO) and water vapour. The concentration of several of these greenhouse gases is rising. The contribution of a number of gases to the global warming is compared in Table 1. Pessimistic scenarios predict that a doubling of the concentration of $\mathrm{CO}_{2}$ and other greenhouse gases will be reached towards the year 2050 (Keepin et al., 1986). Dick- 


\section{A. F. BOUWMAN}

Table 1. Atmospheric concentrations of the major greenhouse gases, their rise, residence time and contribution to the global warming.

\begin{tabular}{|c|c|c|c|c|c|}
\hline Type & $\begin{array}{l}\text { Residence } \\
\text { time }(y)\end{array}$ & $\begin{array}{l}\text { Annual } \\
\text { rise (\%) }\end{array}$ & $\begin{array}{l}1985 \\
\text { concen- } \\
\text { tration }\end{array}$ & $\begin{array}{l}\text { Radiative } \\
\text { absorption } \\
\text { potential }^{8}\end{array}$ & $\begin{array}{l}\text { Contribution } \\
\text { to global } \\
\text { warming }(\%)^{9}\end{array}$ \\
\hline $\mathrm{CO}_{2}$ & $2^{1}$ & $0.5^{2}$ & $345 \mathrm{ppm}^{2}$ & 1 & 45 \\
\hline $\mathrm{CO}^{2}$ & $2-3^{3}$ & $2-6^{3}$ & $90 \mathrm{ppb}^{1}$ & n.a. & $?$ \\
\hline $\mathrm{CH}_{4}$ & $7-8^{4}$ & $1.3^{4}$ & $1.65 \mathrm{ppm}^{6}$ & + & 10 \\
\hline $\mathrm{N}_{2} \mathrm{O}$ & $100-200^{5}$ & $0.25^{5}$ & $300 \mathrm{ppb}^{5}$ & $+t$ & 5 \\
\hline $\mathrm{O}_{3}^{10}$ & $0.1-0.3^{1}$ & $2.0^{1}$ & n.a. ${ }^{7}$ & +++ & 5 \\
\hline CFC's ${ }^{11}$ & $65-110^{1}$ & $3.0^{1}$ & $0.18-0.28 \mathrm{ppb}^{1}$ & ++++ & 25 \\
\hline
\end{tabular}

${ }^{1}$ Ramanathan et al. (1985) (data for 1980); ${ }^{2}$ Bolin (1986); ${ }^{3}$ Khalil \& Rasmussen (1984); ${ }^{4}$ Khalil \& Rasmussen (1985); ${ }^{5}$ Crutzen \& Graedel (1986); ${ }^{6}$ Bolle et al. (1986); ${ }^{7} \mathrm{O}_{3}$ varies from $25 \mathrm{ppb}$ at surface to $70 \mathrm{ppb}$ at $9 \mathrm{~km}$ (Ramanathan et al., 1985); ${ }^{8}$ Swart (pers. comm.); $\mathrm{CO}_{2}=1$, n.a. = not applicable $;+=10-100,++=100-1000,+++=1000-10000,++++=>10000 ;{ }^{9}$ Calculated for period 1980-2030 with data from Ramanathan et al. (1985); ${ }^{10} \mathrm{O}_{3}=$ ozone; ${ }^{11}$ Chlorofluorocarbons; data presented are for the two major CFC's.

inson (1986b) estimated that such an increase will lead to a global warming of between 1.5 to $5.5^{\circ} \mathrm{C}$.

Apart from their role in the atmospheric radiative balance, $\mathrm{CH}_{4}, \mathrm{CO}, \mathrm{N}_{2} \mathrm{O}$ and $\mathrm{NO}$ are known for their interactions with ozone $\left(\mathrm{O}_{3}\right)$. The biogenic sources and sinks of the above-mentioned gases will be discussed in the context of their global budgets. The effect of changing land use on the production of water vapour through evapotranspiration and on the surface heat balance is outside the scope of this paper and will not be discussed.

\section{Global biogenic sources and sinks of greenhouse gases}

\section{Carbon dioxide $\left(\mathrm{CO}_{2}\right)$}

The emissions of $\mathrm{CO}_{2}$ by terrestrial biota, including soil emissions and clearing and burning of forests, have contributed significantly to the present atmospheric $\mathrm{CO}_{2}$ concentration. At present, however, the major source of $\mathrm{CO}_{2}$ is the combustion of fossil fuels. The estimated $\mathrm{CO}_{2}$ emission for 1980 is $5.3 \mathrm{Gt} \mathrm{C} \mathrm{y}^{-1}(\mathrm{Gt}=$ gigaton; $1 \mathrm{Gt}$ $=10^{15} \mathrm{~g}$ ) (Marland \& Rotty, 1983). In projections for the year 2050, Keepin et al. (1986) give estimates of the $\mathrm{CO}_{2}$ emission resulting from fossil fuel combustion ranging between 2 and $20 \mathrm{Gt} \mathrm{C} \mathrm{y}^{-1}$ depending on the application of various techniques of improving the efficiency of fuel use. For comparison: the size of the atmospheric $\mathrm{CO}_{2}$ pool is about $700 \mathrm{Gt} \mathrm{C}$ (Goudriaan \& Ketner, 1984).

There are two approaches to the assessment of the role of terrestrial biota in the $\mathrm{CO}_{2}$ budget. First, there are bookkeeping models which account for rates of deforestation and forest volumes and yield the $\mathrm{CO}_{2}$ release. The best known representatives of this approach are Houghton et al. $(1983,1987)$ and Detwiler \& Hall (1988), who report net biospheric release rates of $1.8 \mathrm{Gt} \mathrm{C} \mathrm{y}^{-1}$ and $1.0 \mathrm{Gt} \mathrm{Cy}^{-1}$ respectively 
Table 2. Comparison of the annual flux of carbon from terrestrial biota by various authors. All figures in $\mathrm{Gt} \mathrm{Cy} \mathrm{y}^{-1}$.

Reference

Present release caused by forest clearings
Present net release including increased net primary production
Bookkeeping models

Houghton et al. (1983)

Houghton et al. (1987)

Detwiler \& Hall (1988)
$1.8-4.7$

$1.0-2.6$

$0.3-1.7$

Dynamic biosphere models

Goudriaan \& Ketner (1987)

Goudriaan (1987)

Esser (1987)

7

2.7
$-0.9$

0 to -0.5

$-0.1$

(see Table 2). The release of $\mathrm{CO}_{2}$ from soils due to forest clearing of 0.1 to $0.3 \mathrm{Gt} \mathrm{C}$ $\mathrm{y}^{-1}$ (Detwiler \& Hall, 1988) and 0.2 to $0.4 \mathrm{Gt} \mathrm{C} \mathrm{y}^{-1}$ (Houghton, pers. comm.) is included in the above figures. In both estimates the formation of charcoal during burning is accounted for.

Secondly, a number of researchers have developed dynamic models of the global carbon cycle including the $\mathrm{CO}_{2}$ injection into the atmosphere by fossil fuel combustion and forest clearing, the role of oceans as a $\mathrm{CO}_{2}$ sink, and the stimulation of growth by $\mathrm{CO}_{2}$. Examples are Goudriaan \& Ketner (1984), who used a simple matrix of conversions of land use and a 12-layer ocean model, and Esser (1987), who used soil, climate and land use data sets and an ocean consisting of 2 layers, all regionalized on a grid of $2.5^{\circ}$ latitude $\times 2.5^{\circ}$ longitude. The r:sults of both dynamic models suggest that at present the biosphere is a net sink of $\mathrm{CO}_{2}$ (see Table 2). The $\mathrm{CO}_{2}$-induced increase of net primary production may be greater than the loss of $\mathrm{CO}_{2}$ caused by deforestation. Goudriaan \& Ketner (1984) postulate that charcoal formation in the process of biomass burning is another important sink of carbon. The point in time where the biosphere turned into a sink of $\mathrm{CO}_{2}$ is around 1970 according to both dynamic models. Further deforestation however, will repress the $\mathrm{CO}_{2}$ fertilizing effect (Esser, 1987). The ever decreasing vitality of forests caused by acid precipitation in industrialized regions may also become increasingly important.

The data pertaining to land use change are difficult to obtain and exceedingly difficult to verify, particularly data from developing countries. Estimates of forest destruction range between 10 and $20 \times 10^{10} \mathrm{~m}^{2} \mathrm{y}^{-1}$, much of it in the Amazonian region (Henderson-Sellers, 1987). Great controversy exists concerning the nature of changes (permanent clearing versus partial destruction or shifting cultivation; the latter process could account for an even greater extent of forest loss than permanent clearing), while definitional differences add to the difficulty of comparing estimates. Brown \& Lugo (1982) reported differences between estimates by various authors of tropical forest volumes of over $200 \%$.

The annual increase of the atmospheric $\mathrm{CO}_{2}$ is about $0.5 \%$ or $3.5 \mathrm{Gt} \mathrm{Cy}^{-1}$. Gou- 
driaan (pers. comm.) estimates that in the absence of other disturbances, an injection of $\mathrm{CO}_{2}$ into the atmosphere will eventually be partitioned over atmosphere, oceans and terrestrial biota in the ratios $0.11,0.71$ and 0.18 ; due to lack of time for redistribution at present the oceans absorb a fraction of only 0.4 . With a $\mathrm{CO}_{2}$ injection of $5.3 \pm 0.5 \mathrm{Gt} \mathrm{C} \mathrm{y}^{-1}$ from fossil fuel combustion (Marland \& Rotty, 1983) and 0.3 to $1.7 \mathrm{Gt} \mathrm{C} \mathrm{y}^{-1}$ from forest clearing (Detwiler \& Hall, 1988), oceans would absorb 2.1 to $3.0 \mathrm{Gt} \mathrm{C}$ annually. The two dynamic biosphere models described above predict an absorption rate of $1.8 \mathrm{Gt} \mathrm{C} \mathrm{y}^{-1}$ by the oceans in 1980 . Using a value of 1.8 $\mathrm{GtC} \mathrm{y}^{-1}$ for oceanic uptake and the high estimates of release rates the budget is balanced with an additional sink of $2.2 \mathrm{Gt} \mathrm{Cy}^{-1}$. With the high value for oceanic uptake and low release rates, there is need for an additional source of $0.9 \mathrm{Gt} \mathrm{Cy}^{-1}$. If these results are attributed to the biosphere, there is an annual change in net primary production of -1.3 to $+3.9 \mathrm{Gt} \mathrm{C} \mathrm{y}^{-1}$ (or -2.1 to $+6.5 \%$ based on net primary production figures given in Goudriaan \& Ketner (1984)). This indicates the uncertainties in the global carbon budget. It also indicates that possibly the fertilizing effect of $\mathrm{CO}_{2}$ is less important than was assumed by Goudriaan \& Ketner (1984) and Esser (1987).

\section{Methane $\left(\mathrm{CH}_{4}\right)$}

Methane is formed during anaerobic decomposition of organic material. Thus, inundated soils or soils with an impeded drainage and the intestinal tract of ruminants are potential $\mathrm{CH}_{4}$ sources. The present global release rate of methane is 329 to $654 \mathrm{Tg} \mathrm{CH}_{4} \mathrm{y}^{-1}\left(\mathrm{Tg}=\right.$ terragram; $1 \mathrm{Tg}=10^{12} \mathrm{~g}$ ) (Bouwman, 1988), while the size of the atmospheric methane reservoir is about $4400 \mathrm{Tg}$ (Bolle et al., 1986). Estimates of the annual increase of atmospheric methane range between $1.1 \%$ (Bolle et al., 1986) and $1.3 \%$ (Khalil \& Rasmussen, 1985). Individual sources are rice paddies (70-170), ruminants (66-90), wetlands (25-70), wastes and landfill sites (3070 ), oceans/lakes/other biogenic sources (15-35), termites (2-42), exploitation of natural gas and coal mining (65-75), biomass burning (55-100). Methane fluxes show a very great temporal and spatial variability. Currently, measurements of soil emissions are being carried out in inverted closed boxes. Extrapolation of results from such point measurements to smaller scales is fraught with potential errors.

The growth of the human world population and the annual increase of the area of paddy rice cultivation $\left(1.1 \% \mathrm{y}^{-1}\right.$ since 1935$)$ correlate well to the $\mathrm{CH}_{4}$ increase in the atmosphere. This indicates that atmospheric $\mathrm{CH}_{4}$ is most likely related to anthropogenic activities. The increase of methane over the past 200 years is probably due to rising emissions $(70 \%)$ whereas a smaller part $(30 \%)$ is possibly caused by a depletion of $\mathrm{OH}$ radicals (Khalil \& Rasmussen, 1985). The latter radicals play a role in the oxidation of (amongst other) methane. Their depletion is caused primarily by the ever larger $\mathrm{CO}$ emission from various anthropogenic sources (see below).

Major methane sinks are: reaction with $\mathrm{OH}$ radicals in the troposphere $(260 \mathrm{Tg}$ $\left.\mathrm{y}^{-1}\right)$, transport to the stratosphere $\left(60 \mathrm{Tg}^{-1}\right)$ (Bolle et al., 1986) and oxidation in arid soils $\left(32 \mathrm{Tg}^{-1}\right)$ (Seiler, 1984). Clearly sources and sinks are not balanced in this budget. 
THE ROLE OF SOILS AND LAND USE IN THE GREENHOUSE EFFECT

\section{Carbon monoxide (CO)}

$\mathrm{CO}$ is not capable of absorbing thermal radiation, but it affects concentrations of $\mathrm{OH}$ radicals. This in turn has an effect on radiatively important gases such as $\mathrm{CH}_{4}$, $\mathrm{O}_{3}$ and CFC's. The major sources of $\mathrm{CO}$ are known, but their magnitudes are still uncertain. The background concentration of $\mathrm{CO}$ is increasing at a rate of 2 to $6 \%$ per year (Khalil \& Rasmussen, 1984), but estimates are uncertain due to fluctuations of sources and sinks and the relatively short residence time of $\mathrm{CO}$ in the atmosphere. Estimates of global CO emission range between 1270 and $5700 \mathrm{Tg} \mathrm{CO} \mathrm{y}$ with an average of $2920 \mathrm{Tg} \mathrm{CO} \mathrm{y}{ }^{-1}$ (Bouwman, 1988). The major sources are biomass burning (800) (Crutzen, 1983), fossil fuel burning (450) (Logan et al., 1981), oxidation of hydrocarbons including methane (680-2380) (Logan et al., 1981). The primary sinks are oxidation to $\mathrm{CO}_{2}$ and soil uptake (3000 and 450, respectively) (Crutzen, 1983). Estimates of the global sink strength range between 1960 and 4750 $\mathrm{Tg} \mathrm{CO} \mathrm{y}{ }^{-1}$ averaging $3600 \mathrm{TgCO} \mathrm{y}^{-1}$. The model is not completely balanced, indicating the uncertainty in the estimates.

\section{Nitrogenous greenhouse gases $\left(\mathrm{N}_{2} \mathrm{O}\right.$ and $\left.\mathrm{NO}\right)$}

Major sources of nitrogenous oxides are nitrification and denitrification processes. $\mathrm{N}_{2} \mathrm{O}$ and $\mathrm{NO}$ are intermediate products, which under certain conditions may escape from being further reduced (denitrification) or oxidized (nitrification). With the available data, Bouwman (1988) attempted in his review to estimate the global biotic sources of nitrous oxide. The global $\mathrm{N}_{2} \mathrm{O}$ emission from cultivated soils (0.3-28 $\mathrm{Tg}^{-1}$ ), natural soils (11-27 $\left.\mathrm{Tg}^{-1}\right)$, emissions due to biomass burning (1-2 $\mathrm{Tg} \mathrm{N}$ $\left.\mathrm{y}^{-1}\right)$ and oceans and estuaries $\left(1-3 \mathrm{Tg} \mathrm{N} \mathrm{y}{ }^{-1}\right)$ yield a likely total global biogenic emission of 13 to $57 \mathrm{Tg} \mathrm{N} \mathrm{y}^{-1}$. For comparison: the global $\mathrm{N}$-fertilizer consumption in 1985 was about $74 \mathrm{Tg} \mathrm{N}$. In the above estimate it is assumed that the emission induced by $\mathrm{N}$-fertilization (0.5-2\% of the $\mathrm{N}$-fertilizer consumption) is included in the flux rate given for cultivated fields. The major non-biogenic source is fossil fuel combustion (1-3 Tg N y${ }^{-1}$ ). All $\mathrm{N}_{2} \mathrm{O}$ is eventually transferred to the stratosphere where it reacts with ozone.

As for $\mathrm{CH}_{4}$, the major problem of giving global estimates of $\mathrm{N}_{2} \mathrm{O}$ fluxes is their extreme spatial and temporal variability. The currently used measurement techniques make their extrapolation a difficult task.

The importance of $\mathrm{NO}$ and its relation to $\mathrm{N}_{2} \mathrm{O}$ production was recognized in recent years. The production ratio of NO: $\mathrm{N}_{2} \mathrm{O}$ is a highly uncertain factor in all such calculations as it is very sensitive to abiotic controls such as oxygen pressure (Levine et al., 1984). Recent research indicates that NO production during nitrification of $\mathrm{NH}_{3}$ in aerobic soils can exceed that of $\mathrm{N}_{2} \mathrm{O}$ (Mosier, 1987). The estimated global NO production in soils is 4-16 $\mathrm{Tg} \mathrm{N}^{-1}$ (Logan, 1983). Other global sources of NO $+\mathrm{NO}_{2}$ are fossil fuel combustion (14-28 $\mathrm{Tg} \mathrm{N} \mathrm{y}^{-1}$ ), biomass burning $\left(4-24 \mathrm{Tg} \mathrm{N} \mathrm{y}^{-1}\right)$ and lightning (2-20 Tg N y$\left.{ }^{-1}\right)$; major sinks are precipitation (12-42) and dry deposition (12-22) (Logan, 1983). Nitric oxide is not able to absorb infrared radiation, but it catalyses various atmospheric reactions in which $\mathrm{O}_{3}, \mathrm{CH}_{4}$ and $\mathrm{CO}$ are involved. 


\section{Discussion}

One of the major conclusions is that the total budgets of greenhouse gases are relatively well known, but the allocation between the various sources needs to be improved. For this purpose the knowledge of the geographic extent of the major soils, soil conditions and ecosystems responsible for these fluxes needs to be improved. At present, there are no global soil and land use maps or digital data sets which are suitable for this purpose. As was discussed above, most of the global geographic information on land use changes is unreliable.

With regard to $\mathrm{CO}_{2}$, all the figures presented in this paper are highly uncertain. The combining of bookkeeping methods with dynamic approaches, as was done in this paper in a very unsophisticated way, will prove helpful in reducing the uncertainties in the estimates of present and predictions of future fluxes of $\mathrm{CO}_{2}$.

Important biomes for $\mathrm{CH}_{4}$ are the natural wetlands, which need to be differentiated according to chemical qualities of the water, vegetation type, characteristics of the peat, water height and climatic conditions; and the areas of wet rice, where more data on soil conditions, land and crop management would form the basis for more reliable flux estimates. Especially natural wetlands in northern areas, where the greatest temperature rises are expected, may in future become much more important sources. Concerning $\mathrm{N}_{2} \mathrm{O}$ and $\mathrm{CO}$, geographic information on soil-specific and land conditions responsible for their fluxes needs improving.

For all the minor greenhouse gases $\left(\mathrm{CH}_{4}, \mathrm{CO}, \mathrm{N}_{2} \mathrm{O}\right.$ and $\left.\mathrm{NO}\right)$ measurement techniques for average fluxes from large ecologically uniform areas need to be developed.

\section{References}

Bolin, B., 1986. How much $\mathrm{CO}_{2}$ will remain in the atmosphere? The carbon cycle and projections for the future. In: Bolin, B., B. R. Döös, J. Jäger \& R. A. Warrick (Eds), The greenhouse effect, climatic change and ecosystems. SCOPE Vol. 29, p. 93-155. Wiley \& Sons, New York.

Bolle, H. J., W. Seiler \& B. Bolin, 1986. Other greenhouse gases and aerosols. Assessing their role in atmospheric radiative transfer. In: Bolin, B., B. R. Döös, J. Jäger \& R. A. Warrick (Eds), The greenhouse effect, climatic change and ecosystems. SCOPE Vol. 29, p. 157-203. Wiley \& Sons, New York.

Bouwman, A. F., 1988. Soils and the greenhouse effect. Working Paper and Preprint No 88/3. International Soil Reference and Information Centre, Wageningen, Netherlands, $143 \mathrm{pp}$.

Brown, S. \& A. E. Lugo, 1982. The storage and production of organic matter in tropical forests and their role in the global carbon cycle. Biotropica 14: 161-187.

Crutzen, P. J., 1983. Atmospheric interactions in homogeneous gas reactions of $\mathrm{C}, \mathrm{N}$ and $\mathrm{S}$ containing compounds. In: Bolin, B. \& R. B. Cook (Eds), The major biogeochemical cycles and their interactions. SCOPE Vol. 21, p. 67-112. Wiley \& Sons, New York.

Crutzen, P. J. \& Graedel, T. E., 1986. The role of atmospheric chemistry in environment-development interactions. In: W. C. Clark \& R. E. Munn (Eds), Sustainable development of the biosphere, p. 213250. IIASA, Laxenburg, Austria. Cambridge University Press.

Detwiler, R. P. \& Hall, C. A. S., 1988: Tropical forests and the global carbon cycle. Science 239: 42-47.

Dickinson, R. E., 1986a. Impact of human activities on climate - a framework. In: W. C. Clark \& R. E. Munn (Eds), Sustainable development of the biosphere, p. 252-289. IIASA, Laxenburg, Austria. Cambridge University Press.

Dickinson, R. E., 1986b. How will climate change? The climate system and modelling of future climate. 
In: Bolin, B., B. R. Döös, J. Jäger \& R. A. Warrick (Eds), The greenhouse effect, climatic change and ecosystems. SCOPE Vol. 29, p. 207-270. Wiley \& Sons, New York.

Esser, G., 1987. Sensitivity of global carbon pools and fluxes to human and potential climatic impacts. Tellus 39B: 245-260.

Goudriaan, J., 1987. The biosphere as a driving force in the global carbon cycle. Netherlands Journal of Agricultural Science 35: 177-187.

Goudriaan, J. \& P. Ketner, 1984. A simulation study for the global carbon cycle, including man's impact on the biosphere. Climatic Change 6: 167-192.

Henderson-Sellers, A., 1987. Effects of change in land use on climate in the humid tropics. In: R. E. Dickinson (Ed.), The Geophysiology of Amazonia. Vegetation and Climate Interactions, p. 463-496. Wiley \& Sons, New York.

Houghton, R. A., J. E. Hobbie, J. M. Melillo, B. Moore, B. J. Peterson, G. R. Shaver \& G. M. Woodwell, 1983. Changes in the carbon content of terrestrial biota and soils between 1860 and 1980: a net release of $\mathrm{CO}_{2}$ to the atmosphere. Ecological Monographs 53: 235-262.

Houghton, R. A., R. D. Boone, J. R. Fruci, J. E. Hobbie, J. M. Melillo, C. A. Palm, B. J. Peterson, G. R. Shaver, G. M. Woodwell, B. Moore, D. L. Skole \& N. Meyers, 1987. The flux of carbon from terrestrial ecosystems to the atmosphere in 1980 due to changes in land use: geographical distribution of the global flux. Tellus 39B: 122-139.

Keepin, W. I. Mintzer \& L. Kristoferson, 1986. Emission of $\mathrm{CO}_{2}$ into the atmosphere. The rate of release of $\mathrm{CO}_{2}$ as a function of future energy developments. In: Bolin, B., B. R. Döös, J. Jäger \& R. A. Warrick (Eds), The greenhouse effect, climatic change and ecosystems. SCOPE Vol. 29, p. 35-91. Wiley \& Sons, New York.

Khalil, M. A. K. \& R. A. Rasmussen, 1984. The global increase of carbon monoxide. In: V. P. Aneja (Ed.), Transactions APCA Specialty Conference, March 1984, Environmental Impact of Natural Emissions, p. 403-414.

Khalil, M. A. K. \& R. A. Rasmussen, 1985. Causes of increasing atmospheric methane: depletion of hydroxyl radicals and the rise of emissions. Atmospheric Environment 19: 397-407.

Levine, J. S., T. R. Augustsson, I. C. Anderson, J. M. Hoell Jr, \& D. A. Brewer, 1984. Tropospheric sources of $\mathrm{NO}_{\mathrm{x}}$ : lightning and biology. Atmospheric Environment 18: 1797-1804.

Logan, J. A. (1983). Nitrous oxides in the troposphere: global and regional budgets. Journal of Geophysical Research 88: 10785-10807.

Logan, J. A., M. J. Prather, S. C. Wofsy \& M. B. McElroy, 1981. Tropospheric chemistry: a global perspective. Journal of Geophysical Research 86: 7210-7254.

Marland, G. \& R. M. Rotty, 1983. Carbon dioxide emissions from fossil fuel: a procedure for estimation and results for 1950-1981. US Department of Energy, DOE/NBB-0036, NTIS, Springfield, Virginia, USA.

Mosier, A. R., 1987. Report of the Biogenic Trace Gas Work Group. Proceedings Workshop on Biological Response to Environmental Change, Woods Hole, USA (in press).

Ramanathan, V., R. J. Cicerone, H. B. Singh \& J. T. Kiehl, 1985. Trace gas trends and their potential role in climate change. Journal of Geophysical Research 90: 5547-5566.

Seiler, W., 1984. Contribution of biological processes to the global budget of $\mathrm{CH}_{4}$ in the atmosphere. In: M. J. Klug \& C. A. Reddy (Eds), Current perspectives in microbial ecology, p. 468-477. American Society of Meteorology. 